\title{
Cikkismertetés: Mik az egészségügy teendői az Egyesült Királyságban?
}

\section{Article review: What to do for the United Kingdom's health system?}

\begin{tabular}{|c|c|}
\hline Ismertető: & Vitrai József \\
\hline Ismertetett cik & $\begin{array}{l}\text { McKee, M., Dunnell, K., Anderson, M., Brayne, C., Charlesworth, A., Johnston-Webber, } \\
\text { C., Knapp, M., McGuire, A., Newton, J. N., Taylor, D., \& Watt, R. G. (2021). The changing } \\
\text { health needs of the UK population. Lancet (London, England), S0140-6736(21)00229-4. } \\
\text { Advance online publication. doi: } 10.1016 / \text { S0140-6736(21)00229-4 }\end{array}$ \\
\hline Kulcss & lakosság egészsége; egészségpolitika; Covid-19 járvány \\
\hline Keywords: & population health; health policy; COVID-19 pandemic \\
\hline
\end{tabular}

Beküldve: 2021. 05. 22., doi: $10.24365 /$ ef.v62i3.6130

Ez az egészségpolitikai dokumentum részletesen áttekintette az Egyesült Királyság (United Kingdom, UK) lakosságának jelenlegi egészségi állapotát és a változó egészségügyi szükségleteket, valamint megvizsgálta, hogy milyen jövőbeli kihívások azonosíthatók. Ezekből a megfontolásokból, valamint a tanulmányban idézett 120 szakcikk, -dokumentum alapján a neves szerzők több következtetést fogalmaztak meg.

Először is, a várható élettartam jelentős javulása ellenére számos fizikai és mentális egészségügyi mutató elmaradást mutat más magas jövedelmű országokhoz képest. Ezt a kedvezőtlen állapotot az okozza, hogy minden korosztályban, de különösen gyermekkorban és időskorban a lakosság körében magas a megelőzhető megbetegedések aránya, melyek igazságtalanul oszlanak meg a társadalomban. Mivel a UK-ban viszonylag magas a Covid-19-nek tulajdonítható többlethalálozási arány, a várható élettartamban a UK és más fejlett országok közötti különbség valószínűleg növekedni fog.

Másodszor, a jövőben a munkaképes lakosság számának csökkenésére kell számítani, különösen, ha a jelenlegi bevándorlási politika folytatódik, és jelentősen nő a komplex multimorbiditással élők száma. Ez a fejlődési pálya a szükségletek és a kielégítésükre szolgáló kapacitás közötti eltérést fog eredményezni, mind a munkaerő rendelkezésre állása, mind a fenntartható finanszírozás gazdasági alapjának biztosítása révén. E problémák kezelése érdekében nagyobb hangsúlyt kell fektetni a megelőzésre és az egészség- fejlesztésre, amely több ágazatot átfogó megközelítéssel kezeli a rossz egészségi állapot társadalmi, politikai és kereskedelmi okait. Kifejezetten foglalkozni kell azzal a döntő szereppel, amelyet az Országos Egészségügyi Szolgálat (National Health Service, NHS) játszhat azáltal, hogy egészségbarát munkáltatóként példát mutat, csökkenti a krónikus betegségek kockázati tényezőit, elősegíti az egészséges öregedést, erősíti a bizalmat és támogatja a társadalmi szerepvállalást. Az NHS azonban egyre inkább olyan környezetben múködik, amelyben más ágazatok — kiemelten a szociális ellátás támogató szerepe csökken az általános megszorítások következtében.

Végezetül számos olyan közvetlen fenyegetés van, amely hatással van a lakosság egészségére és a szolgáltatásnyújtásra. Kulcsfontosságú, hogy a UK-nak stratégiát kell kidolgoznia a Covid-19 világjárvány szélesebb körű és hosszú távú egészségügyi következményeinek enyhítésére. Ezenkívül a UK-nak az Európai Unióból való kilépése, a növekvő antimikrobiális rezisztencia és a fokozódó éghajlatváltozás mind olyan nagy kihívások, amelyek jelentős következményekkel járnak az NHS-re nézve. Más előre nem látható kockázatok, mint például a gazdasági visszaesés vagy egyéb társadalmi krízis hatással lennének az NHS-re, de ezekre nehéz előre tervezni. Ehelyett a hangsúlyt egy rugalmas és megelőzésközpontú egészségügyi szolgáltatás kiépítésére kell helyezni, hogy az NHS jobban felkészült legyen a jövőbeli kihívásokra. 


\section{TANULSÁGOK A HAZAI SZAKEMBEREK SZÁMÁRA}

Érdemes lenne a vezető magyar népegészségügyi szakembereknek is egy hasonló "számvetést" végezniük, és mielőbb következtetéseket levonni a lakosság egészségének elemzése, valamint a Covid-19 járvány tapasztalatainak értékelése alapján. Minden valószínűség szerint a hazai szakértők is olyan következtetésekre juthatnak, hogy "nagyobb hangsúlyt kell fektetni a megelőzésre és az egészségfejlesztésre, amely több ágazatot átfogó megközelítéssel kezeli a rossz egészségi állapot társadalmi, politikai és kereskedelmi okait".

Információk a szerzőről:

Vitrai József, független népegészségügyi szakértő, vitrai.jozsef@gmail.com 